\title{
Chemotherapeutical Analysis of 2-Pyrazinoyl Hydrazide and 2- Pyrazinoyl Hydrazones against Some Bacteria
}

\author{
Ravish Kumar Chauhan \\ Associate Professor, Department of Chemistry, Indira Gandhi National College, Ladwa-136132, Kurukshetra, Haryana, India
}

\begin{abstract}
Various ligands possess medicinal properties. The chelating ligands act as more active medicinal agent than non-chelating ligands. Derivatives like oximes, semicarbazones, and hydrazones of benzaldehyde and substituted benzaldehydes have long been prepared and analyzed by chemists for antibacterial, fungicidal, anti-inflammatory and analgesic activities. The ligands which are active against micro-organisms like bacteria, fungi, or virus can act as a tool in medicinal chemistry. In view of these facts here we have undertaken the screening of 2-pyrazinoyl hydrazide and its derivatives with various aromatic and heterocyclic aldehydes against various bacteria. The present paper deals with the action of bacteria, occurrence, their cultivation and culture and their screening using hydrazones derivatives of 2-pyrazinoyl hydrazide with various aromatic and heterocyclic aldehydes such as benzaldehyde, anisaldehyde, 4-hydroxy-3-methoxy benzaldehyde, p- (N,N-diethyl amino) benzaldehyde, cinnamaldehyde, 4-methyl salicyldehyde and 2furfuraldehyde.
\end{abstract}

Keywords: Bacteria, Infection, Chelating ligands, Hydrazones, Antibacterial

\section{Introduction}

Although microorganisms were known to be associated with many diseases, but the relationship between microorganism and the disease was a matter of speculation. This was later established by Robert Koch. ${ }^{(1)}$ Bacteria are the most abundant, living creature on the earth, the number and types of bacteria ${ }^{(2)(3)}$ is enormous, the majority are free living and play a vital role in the economy of nature, in the circulation of carbon, nitrogen and other elements; rest are parasitic either on animals or on plants and causes a number of diseases. When microorganisms enter the body of human beings or animals, they multiply and produce a reaction. It is termed as infection. The reaction of body may or may not be accompanied by outward signs of the disease. However, the mere presence of microbes in the body does not mean infection because micro-organisms normally inhabit many parts of the body without invading the deeper tissues to cause disease. Many drugs or agents are used either to prevent the entering bacteria or to treat the disease caused by them. The part of the biomolecule being affected by the antimicrobial drugs is called receptor. Protein of the cell forms the most important class of the drug receptor. The binding of drug to receptor in various cases involves all known types of interactions i.e., ionic, Vander Waals, covalent, etc. In most such interactions the bonds of multiple types are important and are formed between the reactive groups on the drug and complementary appropriately oriented regions of the receptor. Thus the compounds having functional groups which can react with protein form potential drugs. If the atoms of the reaction species are not in proper special orientation they will not fit into the receptor site and will thus be ineffective. In order to have strong interactions between the compound and receptor site there must be proper spatial arrangement of atoms and compatible charge distribution.

\section{Action of Antibacterial}

The substances used as antimicrobial manifest their activity ${ }^{(4)}$ in one of the several ways. In a general way one may view the possible sites of action of an antimicrobial agent by recalling certain features of the microbial cell. A normal living cell contains the multitude of enzymes responsible for metabolic process. A semipermeable membrane (cytoplasmic membrane) maintains the integrity of the cellular contents; the membrane selectively controls the passage of substances between the cell and its external environment and is also the site of some enzyme reactions. The cell wall proper provides a protective covering to the cell in addition to participating in certain physiological processes. Damage at any one of these levels may initiate the changes leading to the death of the cell.

(a) Damage to cell wall: Some agents may inhibit the formation of cell wall material in a growing bacterial culture with the resulting formation of protoplast. The antimicrobial effect of penicillin is attributed to its inhibition ${ }^{(5)(6)(7)}$ of cell wall synthesis.

(b) Alteration of cell permeability: The cytoplasmic membrane preserves the integrity of the cellular constituents as well as the selective transport of nutrient into the cell; damage to this membrane may result in the inhibition of growth or the death of the cell. The antimicrobial activity of phenolic compounds, synthetic detergents, soaps and quaternary ammonium compounds ${ }^{(8)}$ is attributed to their effect on cell permeability. These substances destroy the selective permeability of the membrane, permitting leakage of cellular constituents.

(c) Alteration of protein and nucleic acid molecule: The viability of a cell is associated with maintenance of protein and nucleic acid molecule in their natural state. A condition or substance which alters this state i.e., denatures the proteins or nucleic acids, may irreparably damage the 


\section{International Journal of Science and Research (IJSR) \\ ISSN (Online): 2319-7064}

Index Copernicus Value (2013): 6.14 | Impact Factor (2014): 5.611

cell. High temperatures and high concentration of some chemicals (e g., tetracycline, chloramphenicol ${ }^{\left({ }^{9}\right)}$ etc.) can bring about irreversible coagulation (denaturation) of these vital protoplasmic constituents.

(d) Inhibition of enzyme action: Each of the hundreds of different enzymes in the cell is a potential target for an inhibitor. Inhibition of energy supplying reaction may be particularly detrimental, many agents effect enzymes in their key path ways e g. the glycolytic system, the Krabs tricarboxylic acid cycle and the cytochrome system. For example, cyanides inhibit oxidase, fluoxide inhibits glycolysis and trivalent arsenic compounds block the tricarboxylic acid cycle. Strong oxidizing agent e.g., halogens and hydrogen peroxide, may damage cellular constituents to such an extent that they can no longer perform normal metabolic functions. For example, the activity of many enzymes depends upon one of their components sulfhydryl group, - $\mathrm{SH}$, an oxidizing agent may alter this chemical arrangement and inactivate the enzymes.

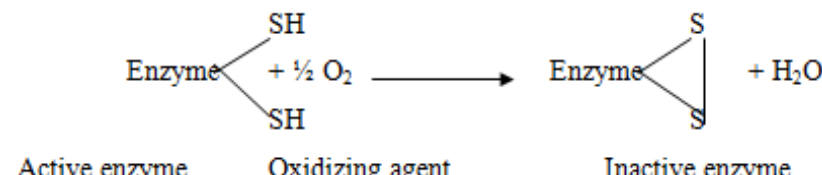

Inactivation of certain enzymes may come about as a result of combination with some metallic ion such as silver, copper, and mercury. Its effect is upon the sulfhydryl group.

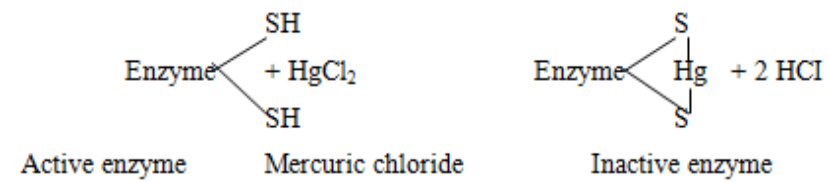

The ability of extremely small amounts of certain heavy metals, particularly silver, to exert a lethal effect upon bacteria is designated oligodynamic action; from the two Greek words oligos, meaning small, and dynamic, meaning power. The effectiveness of these small amounts of metallic ions is believed to be due to the high affinity of certain cellular proteins for the ion.

(e) Antimetabolites: There are some instances of inhibition ${ }^{(10)}$ in which the initial lesion is interference in a specific biosynthesis. A classical example is the blockage of folic acid synthesis by sulfanilamide. One of the components of the folic acid molecule is p-aminobenzoic acid ${ }^{(11)}$ whose chemical structure is very similar to that of sulfanilamide. The sulfanilamide competes with the paminobenzoic acid for the enzyme surface, thereby preventing synthesis of the essential folic acid. Many other synthetic processes can be interrupted by a compound, structurally related to, but slightly different from the natural metabolites. Such a substance is known as antimetabolite.

(f) Inhibition of nucleic acid synthesis: Certain synthetic chemicals and some naturally occurring substances are powerful inhibitors of RNA and DNA synthesis. The categories of substances inhibiting nucleic acid synthesis, (a) Compounds that interfere with the formation of building blocks of nucleic acid, normally the purine and pyrimidine nucleotides, (b) Compounds that interfere with polymerization of nucleotides into nucleic acids. The vital role of DNA and RNA in the normal life process of the cell suggests that any interference with their formation would seriously impair the cell. Substances that act in this manner are griseofulvin.

In general it may be concluded that agents who damage the cell wall in the cell membrane are bactericidal; those which interfere with an enzyme action are bacteriostatic.

\section{Materials and Method}

The ligands Pyrazine-2-carboxylic acid hydrazide ${ }^{(12)}$ $\left(\mathrm{C}_{5} \mathrm{H}_{6} \mathrm{~N}_{4} \mathrm{O} ; \mathrm{PAH}\right)$ and its hydrazones derivatives with different aldehydes viz. Benzyllidene-2-Pyrazinoyl hydrazone $\left(\mathrm{C}_{12} \mathrm{H}_{10} \mathrm{~N}_{4} \mathrm{O}\right.$; PAH- BENZ), Anisalidene-2pyrazinoyl hydrazone $\left(\mathrm{C}_{13} \mathrm{H}_{12} \mathrm{~N}_{4} \mathrm{O}_{2}\right.$; PAH- ANSL ), 4Hydroxy-3-methoxy benzylidene-2-pyrazinoyl hydrazone ( $\left(\mathrm{C}_{13} \mathrm{H}_{12} \mathrm{~N}_{4} \mathrm{O}_{3}\right.$; PAH- VANI ), p - (N, N - diethylamino) benzyllidene-2-pyrazinoyl hydrazone $\left(\mathrm{C}_{16} \mathrm{H}_{19} \mathrm{~N}_{5} \mathrm{O}\right.$; PAHPDEAB), Cinnamalidene-2-pyrazinoyl hydrazone $\left(\mathrm{C}_{14} \mathrm{H}_{12} \mathrm{~N}_{4} \mathrm{O}\right.$; PAH- $\left.\mathrm{CAH}\right)$, 4-Methyl salicylidene-2pyrazinoyl hydrazone $\left(\mathrm{C}_{13} \mathrm{H}_{12} \mathrm{~N}_{4} \mathrm{O}_{2}\right.$; PAH- MSALI ), 2Furfuralidene-2'- pyrazinoyl hydrazone $\left(\left(\mathrm{C}_{11} \mathrm{H}_{10} \mathrm{~N}_{4} \mathrm{O}_{2}\right.\right.$; PAH- FURAL) have been screened for their bactériostatic activity against some human pathogen. The brief description of these has been given below.

(a) Escherichia coli: It inhabits human and animal intestinal tract. ${ }^{(13)}$ These organisms are gram (-ve), nonsporing, occasionally encapsulated, variably motile bacilli, 0.5 to $0.7 \mu \mathrm{m}$ in width and 1 to $4 \mu \mathrm{m}$ in length, occur either singly, in pair, or in long chains. They sometime occur in oval or coccal shapes and occasionally as very long filaments, they vary from colourless to grayish white.

E. coli is aerobic or facultatively anaerobic and is easily grown on common laboratory media. Although optimum growth occurs at $37^{\circ} \mathrm{C}$, growth is also obtained over a temperature range of $10^{\circ} \mathrm{C}$ to $46^{\circ} \mathrm{C}$. The resistance of $\mathrm{E}$. coli to heat, in average for only a few strains survives $60^{\circ} \mathrm{C}$ for 30 minutes.

E. coli is not only very pathogenic for either men or animals, but it is a major source of vitamin $\mathrm{K}^{(14)}$ and in some persons a secondary source ${ }^{(15)(16)}$ of vitamin $\mathrm{B}_{2}$. Infection with E. coli occurs occasionally in the appendix and gall bladder wounds.

(b) Staphylococcus aureus: The staphylococci are a group of gram (+ve), spherical bacteria that form irregular cellular aggregation or group like clusters but seldom forms chains when grown in liquid medium. The pathogenic staphylococci grow abundantly at temperature ranging from $35-37^{\circ} \mathrm{C}$. They grow best on a slightly alkaline medium ( $\mathrm{pH} 7.40)$. They are resistant to heat $\left(60^{\circ} \mathrm{C}\right.$ for 30 minutes). They are non-sporing, non-motile, facultatively anaerobic. 


\section{International Journal of Science and Research (IJSR) \\ ISSN (Online): 2319-7064}

Index Copernicus Value (2013): 6.14 | Impact Factor (2014): 5.611

S. aureus is a parasitic and pathogenic. (17)(18) The staphylococcus causes a wide variety of diseases in man. S. aureus is a common inhabitant of human skin, throat ${ }^{(19)}$ and mucous membrane. It is also a pathogenic bacterium of milk. Bovine mastitis is an inflammatory and highly communicable disease caused by $\mathrm{S}$. aureus. The most common type of food poisoning is generally referred as staphylococcus or staph food poisoning. ${ }^{(20)}$

(c)Klebsiella pneumoniae: Kiepsiella pneumoniae called friend landor's bacilli was first isolated from the lung of a patient dying with pneumonia, is a normal inhabitant of nasal, oral cavities and the intestinal tract. ${ }^{(21)}$ It is involved in respiratory and some supportive infections. ${ }^{(22)}$ It is a gram (-ve),non-sporing, non-motile, facultatively anaerobic rod, 0.3 to $0.5 \mu \mathrm{m}$ in width by 2 to $5 \mu \mathrm{m}$ in length, growth occurs on usual agar media between $15^{\circ} \mathrm{C}$ to $40^{\circ} \mathrm{C}$, with an optimum temperature of $37^{\circ} \mathrm{C}$. K.

NCBI No.
(a) Escherichia coli
(b) Staphylococcus aureus
(d) Bacillus pumilus
(e) Bacillus subtilis
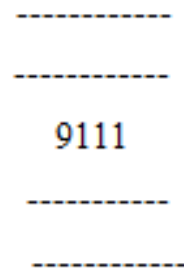

Pneumoniae is present in less than $5 \%$ of all normal human respiratory tracts. Pneumonia by $\mathrm{K}$. pneumoniae is highly fatal.

(d)Bacillus pumilus: It is rod-like in shape, with zig-zag twisting, 0.2 to $2.5 \mu \mathrm{m}$ by 1.32 to $7.2 \mu \mathrm{m}$. Gram positive, found in moist soil ${ }^{(23)}$ and sewage.

(e)Bacillus subtilis: It is rod-shaped, 0.3 to $2.2 \mu \mathrm{m}$ by 1.27 to $7.0 \mu \mathrm{m}$. Majority motile flagella typically lateral. Endospores formed, not more than one in a sporangial cell, $\underset{(23)}{\text { gram }}(+v e)$, chemoorganotrophs. Commonly found in soil.

NCBI No, ATCC No and NCTC No. of test organisms used in experiment are as follows.

$\begin{array}{cc}\text { ATCC No. } & \text { NCTC No. } \\ 10536 & - \\ 29737 & - \\ 10031 & - \\ 14884 & 8241 \\ 6633 & 8236\end{array}$

\section{Techniques Used for Bacteriological Studies}

i. Liquid media assay or dilution method

ii. Agar-streak method

iii. Diffusion method

iv. Turbidimetric method ${ }^{(24)}$

v. Agar plate method

vi. Phenol coefficient method

The most suitable one and adopted in the present study is given below:

\section{Cup Plate Method}

ii. Dry heat,

iii. Radiant energy,

iv. Ultrasonic vibration,

v. Filtration, etc.

\section{(ii) Chemical methods:}

i. Bactericidal agents,

ii. Bacteriostatic agents,

iii. Disinfectants and antiseptics,

iv. Germicides,

v. Antimicrobial drugs,

vi. Antibiotics, etc.

Of these moist heat and dry heat method were found suitable for this work.

\section{(b) Measurement of bacteriostatic action}

For the measurement of the activity of disinfectant or bacteriostatic agents, the first requisite is the standardization of the procedure. To express the bacteriostatic or germicidal activity on a numerical basis; numerous procedures have been developed e.g.
Agar-plate technique was employed for the determination of antibacterial spectrum with some modification by cutting cylinder of $8 \mathrm{~mm}$ diameter in agar plate in place of paper disc, nutrient agar medium was used. Method involves the following steps.

(a) Preparation and sterilization of media.

(b) Sterilization of the glass apparatus.

(c) Inoculation of media with microorganism.

(d) Pouring of the seeded medium into the sterilized Petri dishes and cutting of cups.

(e) Incubation at specified temperature, and

(f) Determination of zone of inhibition.

(i) Nutrient media: Many different types of culture media have been employed in the study of bacteria, but most of well known heterotrophic species (those bacteria which requires one or more performed organic compounds among the materials that are used for food) will grow in peptone or peptone-beef extract medium fortified if necessary with sugars or with specific growth factors. Various nutrient broths ${ }^{(25)}$ were used in the laboratory for 


\section{International Journal of Science and Research (IJSR) \\ ISSN (Online): 2319-7064}

Index Copernicus Value (2013): 6.14 | Impact Factor (2014): 5.611

growing bacteria; peptone-beef extract broth has been found suitable for the study.

(ii)Preparation of experimental broth: The nutrient medium consists of peptone beef and is prepared by dissolving the following quantities (in $\mathrm{g}$ ) of the specified ingredients in sufficient purified water to produce $1000 \mathrm{ml}$ of medium

Peptone 5.0

Yeast extract 3.0

Beef extract 1.5

Agar 15.0

Final pH 6.5 - 6.6 (after sterilization)

Sub cultures were made in standard broth at twenty four hr. intervals, three times, before the test was carried out and a twenty four hr. broth culture was used for the test purpose.

(iii)Procedure for assay: This method depends on the diffusion of compounds from a cavity through the solidified agar layer of a Petri dish to an extent such that growth of the added microorganism is prevented entirely in a circular area or zone around the cavity containing the solution of the compound.

The measured quantities of the cultures of the test organism $(0.2 \mathrm{ml}$ per $100 \mathrm{ml})$ were added to heated (nearly $45-50^{\circ} \mathrm{C}$ ) medium and the inoculated media was immediately poured into the sterilized Petri dishes to give a uniform depth of 3 to $4 \mathrm{~mm}$ and then allowed to set on an even surface. There after it was transferred to a refrigerator maintained at $5 \pm 2{ }^{\circ} \mathrm{C}$ (to minimize the effect of variation in time between the applications of the different solution). The prepared plates must be stored in a manner so as to ensure that no significant growth or death of the test organism occurs before dishes are used and that the surface of the agar layer is dry at the time of use.

Table 1: Incubation Temperature for various Bacteria

\begin{tabular}{|l|c|}
\hline \multicolumn{1}{|c|}{ Bacteria } & Incubation temperature $\left({ }^{\circ} \mathrm{C}\right)$ \\
\hline (a) Escherichia coli & 35.40 \\
\hline (b) Staphylococcus aureus & 32.00 \\
\hline (c) Klebsiella pneumoniae & 35.40 \\
\hline (d) Bacillus pumilus & 38.00 \\
\hline (c) Bacillus subtilis & 32.00 \\
\hline
\end{tabular}

The test solution of Pyrazine-2-carboxylic acid hydrazide and its hydrazones derivatives were prepared by taking their concentrations, $1.0 \mathrm{mg} / \mathrm{ml}$ in dimethyl sulphoxide (DMSO) and $0.2 \mathrm{ml}$ of each were poured into the cups made by a sterilized cutter. All Petri dishes were again put in the refrigerator for at least one hour in order to allow diffusion of the solution and then transferred to incubator maintained at specified temperature (Table 1.) for about eighteen hours. All the tests were run in triplicate and the average zones of inhibition were noted. The zone of inhibitions around the holes, were measured with the help vernier caliper and data was summarized in the table 2.The activities are represented by diameter of zone of inhibition (mm).

Table 2: Antibacterial activity of pyrazine-2-carboxylic acid hydrazide (PAH) and its various derivatives against gram positive and gram negative organisms

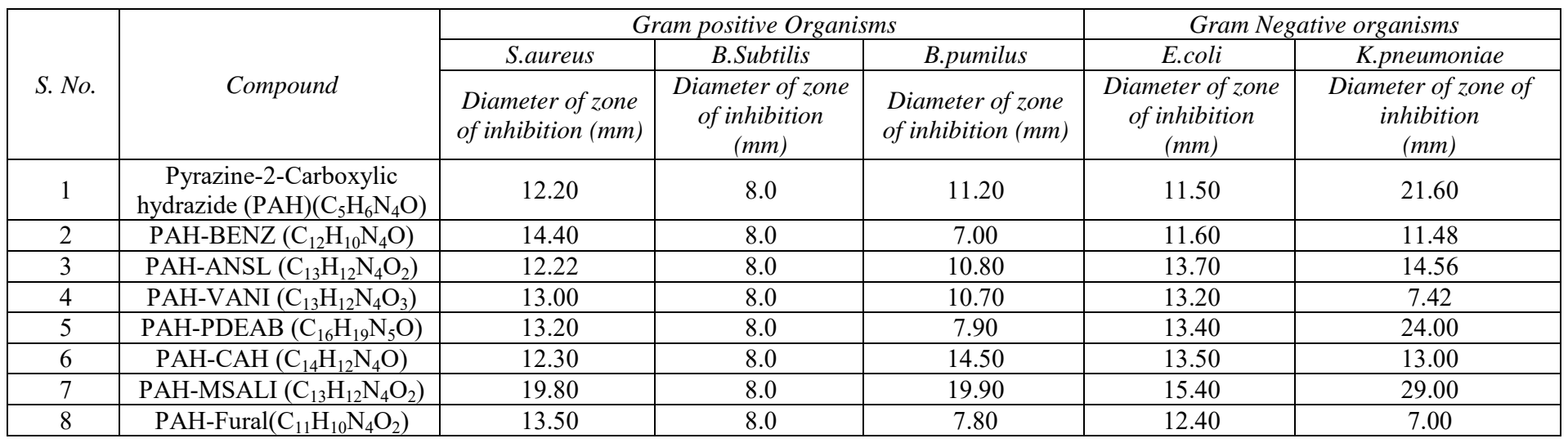

(1) Zones of inhibition $(\mathrm{mm})$ are the mean of three experimental observations.

\section{Results and Discussion}

2-Pyrazinoyl acid hydrazide and its hydrazones with different aldehydes were screened for antibacterial activity. From the data it is evident that all the compounds studied are inactive against B. subtilis and their activity is in order K. pneumonia $>$ S. aureus $>$ E. coli $>$ B. Pumilus and among hydrazide and hydrazones the most active compound is PAH-MSALI and least active is PAH-Fural.

\section{Acknowledgement}

The author is indebted and grateful for the technical help and useful suggestions rendered by Dr. R. K. Bhardwaj, Associate Professor of Chemistry, D. S. College Karnal (Haryana) India, Dr. S. N. Mittal, Associate Professor of Chemistry, M. L.N. College Yamuna Nagar (Haryana) India and Dr. P. K. Sehgal, Zoologist, Dehradun (Uttara Khand) India in preparing and presenting this paper. 


\section{References}

[1] O'Brien S.J., Goedert J.J. (1996). Current Opinion in Immunology 8 (5): 613-8.

[2] Whitman W.B., Coleman D.C., Wiebe W.J. (1998). Proceedings of the National Academy of Sciences of the United States of America 95 (12): 6578-83.

[3] Hogan C.M. (2010). Bacteria. Encyclopedia of Earth. eds. Sidney Draggan and C.J.Cleveland, National Council for Science and the Environment, Washington DC

[4] Bandow J. E.,Brotz H., Leichert L. I., Labischinski H. and M. Hecker M.( 2003). Antimicrob. Agents Chemother. 47:948-955.

[5] Tomasz A. (1979) Ann Rev Microbiol 33:113-37.

[6] Tomasz A. (1986) Rev Infect Dis :S260-78

[7] Yocum R.R., Rasmussen J.R., Strominger J.L. (1980) J Biol Chem .255:3977-86.

[8] Harris R.. S., Bunker J.W.M.( 1932). Proc. Am. Acad. Arts Sci. 67: 147.

[9] Gale E. F. Folkes J. P. (1953). Biochem. J. 53, 493.

[10] Smith A. L. (1997). Oxford dictionary of biochemistry and molecular biology. Oxford: Oxford University Press. p. 43.

[11] Silverman R. B. (2004). The Organic Chemistry of Drug Design and Drug Action (2nd edition)

[12] Chauhan R. K., (2015). International Journal of Medicine and Pharmaceutical Science, Vol. 5 (6): 4352.

[13] Singleton P. (1999). Bacteria in Biology, Biotechnology and Medicine (5th ed.). Wiley. pp. 444-454.

[14]Bentley R.., Meganathan R. (1982). Microbiological Reviews 46 (3): 241-80.

[15] Hudault S., Guignot J., Servin A.L. (2001). Gut 49 (1): 47-55.

[16] Reid G., Howard J., Gan B.S. (2001). Trends in Microbiology 9 (9): 424-428.

[17] Kluytmans J., van Belkum A., Verbrugh H., Van Belkum, Verbrugh. (1997). Clin. Microbiol. Rev. 10 (3): 505-20.

[18] Lowy F.D. (1998) Trends Microbiol 8: 341-344.

[19] Cole A. M.., Tahk S., Oren A.,Yoshioka D., Kim Y. H., Park,A., Ganz T. ( 2001). Clin Diagn Lab Immunol 8 (6): 1064-9.

[20] Le Loir Y., Baron F., Gautier M.(2003). Genet. Mol. Res.2:63-76.

[21]Ryan K.J., Ray C.G. eds. (2004). Sherris Medical Microbiology (4th ed.). McGraw Hill.

[22] Nordmann P., Cuzon G., Naas T. (2009) Lancet Infect Dis. 9(4):228-36.

[23]Priest F.G. (1993) Systematics and Ecology of Bacillus. In: Sonenshein A.L., Hoch J.A., Losick R, editors. Biochemistry, Physiology, and Molecular Genetics. Washington, D.C.: ASM Press. pp. 3-16.

[24] Grove D.C. and Randall W.A.(1955) Medical Encyclopaedia, Inc., New York 238.

[25] Difco Manual, 9th Ed. (1953). Difco Laboratories Inc. Detroit, Michigan 